\title{
FACULTY DEVELOPMENT BEYOND INSTRUCTIONAL DEVELOPMENT
}

\author{
IDEAS CENTERS CAN USE
}

Mary Deane Sorcinelli, University of Massachusetts Amherst Tara Gray, New Mexico State University A. Jane Birch, Brigham Young University

Most faculty development programs focus on the faculty member as teacher. However, faculty seek support in many areas, including orientation, mentoring, scholarly writing, time management, career advancement, leadership, and service. Research and practice also suggest that faculty and faculty development programs benefit from an integrated approach to professional development. This chapter fills a gap in faculty development practice by suggesting ways that centers can create programming that goes beyond instructional development, thereby supporting a more expansive range of faculty work.

A large-scale study of the field of faculty development indicates that many programs focus primarily on enhancing teaching and learning (Sorcinelli, Austin, Eddy, \& Beach, 2006). Quality teaching and learning is critical for student development, and it has become increasingly complex, requiring new skills of faculty members and faculty developers.

\footnotetext{
We thank the following people who graciously read and responded to earlier drafts of this chapter: Kate Brinko, Tom Brinthaupt, Jo Clemmons, Jean Conway, Rene Hadjigeorgalis, Mark Hohnstreiter, Pam Hunt, Cathy Luna, Laura Madson, and Lynn Sorenson.
} 
At the same time, research indicates that early-career faculty members, especially women and faculty of color, encounter challenges beyond their teaching role that can have a negative effect on their productivity and career advancement. These roadblocks include getting oriented, finding mentors, excelling in scholarship, creating work-life balance, navigating the tenure track, and leading effectively (Rice, Sorcinelli, \& Austin, 2000; Yun \& Sorcinelli, 2009). A comprehensive faculty study that Schuster and Finkelstein (2006) conducted also concludes that the nature of faculty work is increasingly multifaceted, thereby requiring professional development in more areas.

Faculty developers are well aware of expectations for faculty to fulfill new and expanding roles and responsibilities. Some have called for faculty development programs that better align with organizational goals (Morahan, Gold, \& Bickel, 2002; Palmer, Dankoski, Brukiewicz, Logio, \& Bogdewic, 2010). Others note that centers need to create multiple entry points for faculty development by serving needs other than instructional development: "A broad mandate . . may give faculty more reasons to use the center" (Gray \& Shadle, 2009, p. 8). Indeed, some faculty development centers have already adopted broader missions and ventured into additional programming areas, most notably new faculty orientation and mentoring programs. Fewer faculty development centers have engaged in scholarly writing, career advancement, time management, work-life balance, and leadership development, including department head training (Lee, 2010).

In this chapter, we explore ways that developers can address the roadblocks to faculty success by implementing programs that go beyond instructional development. We present ideas that have proven successful in terms of participation rates and ratings of overall effectiveness (assessment data are available from the authors). These efforts have been tested at three very different universities: New Mexico State University (NMSU), Brigham Young University (BYU), and University of Massachusetts Amherst (UMass). These universities differ in student enrollment, faculty, research classification, and private or public designation. Their centers also differ in size of staff devoted to faculty development beyond instructional development: 1.5 professional full-time equivalent (FTE) at NMSU, 3.5 at BYU, and 2.5 at UMass.

Each of these universities has created opportunities for faculty to get oriented, find mentors, strengthen scholarly writing, manage time, navigate the tenure process, and develop leadership skills. We encourage developers to venture into these emerging areas of practice, adapting ideas to the goals and resources of their own centers and institutions and 
thereby embody a more holistic, multifaceted definition of faculty development.

\section{Getting Oriented}

New faculty members are an important clientele for every faculty development center. Serving new faculty well during their initial year on campus establishes a solid platform for continued engagement with them throughout their careers. New faculty are especially open to assistance, and women and faculty of color, who often lack more informal support systems, are particularly well served by formal programs that help them negotiate a new environment (Sorcinelli \& Yun, 2007). Also, helping faculty get off to a good start is a smart investment for institutions. The hiring process is time-consuming and expensive; the university profits when new faculty flourish and are retained (Bensimon, Ward, \& Sanders, 2000).

New faculty orientations can take many forms. New or small centers might consider piloting a modest program. For example, at NMSU, the center provides two half-day orientations for new faculty so that they are not overloaded with information on arrival. These short orientations feature the provost and several other speakers and panels on topics such as teaching, scholarly writing, research, and promotion and tenure. In addition, new faculty members are encouraged to choose from more than one hundred workshops, courses, and short courses provided to all faculty each year that address a range of professional and institutional questions.

At UMass, the center's new faculty orientation extends across two semesters, helping newcomers develop both academic and social networks. Just prior to fall semester, new faculty (tenure-track and full-time contract faculty) spend a day getting to know each other and the campus, hearing from a panel of near peers, and experiencing a "progressive luncheon" with key service providers from the library, academic computing, faculty development, research affairs, and student life. The chancellor then hosts a reception at his home where new faculty, their spouses and partners, and senior administrators are introduced to each other. In spring semester, the chancellor and associate provost for faculty development invite all new tenure-track faculty to small group breakfasts, providing them a chance to take stock, ask questions, and reconnect with peers. All new faculty are also invited throughout the year to participate in workshops and apply for internal grants related to their contextspecific professional needs. 
BYU offers a multiformat eighteen-month program for all new tenuretrack professors. The program begins with seven lunch sessions during fall semester, featuring topics that serve the needs of new faculty during their initial year. By the start of second semester, new faculty members choose a faculty colleague to serve as their mentor. Mentors and protégés come together to a February training meeting and are encouraged to meet regularly thereafter. In May, the new faculty members attend an intensive two-week seminar (meetings in the morning, homework in the afternoon). During the seminar, participants explore an array of faculty issues in greater depth, as well as connect with each other and key administrators. They also work on individual development plans and design three projects to pursue in the upcoming year (one each in teaching, scholarship, and service). The program concludes the following March with project reports and a celebratory banquet. To encourage participation, BYU provides a stipend of two thousand dollars to each participant who completes the program.

\section{Mentoring}

Mentoring helps new faculty members in many ways, resulting in better teaching evaluations, socioemotional support, political savvy, research productivity, and career success (Boice, 1990; Johnsrud \& Atwater, 1993; Johnson, 2007). Unfortunately, spontaneous mentoring occurs for only about 30 percent of all new faculty (Boice, 2000; Goodwin \& Stevens, 1998), and "nontraditional hires and newcomers who struggled most were even more likely to go unmentored" (Boice, 2000, p. 238).

Formal mentoring programs need not match protégés with one partner, as is the tradition. Some of the most successful mentoring programs allow the protégé to select his or her own mentor. In fact, research suggests that more successful mentoring relationships occur after the protégé meets with several possible mentors before choosing one (Boice, 2000). Furthermore, several recent studies suggest that faculty with multiple mentors reap greater career benefits than those with just one (van Emmerik, 2004; Yun \& Sorcinelli, 2009) and that a networking model of mentoring may be more inclusive of women and minorities (Sorcinelli $\&$ Yun, 2007). Therefore, mentoring programs should encourage faculty to develop a broad, flexible network of mentoring relationships and to consider peers, near peers, and senior colleagues as potential mentoring partners.

New Mexico State University hosts a large (more than one hundred faculty) multiyear mentoring program designed to give pretenure faculty 
members a mentor from their first year through tenure. In this program, new faculty members are paired with more senior faculty by a committee of faculty members who know many faculty members across campus. In addition, two luncheons and two mixers are hosted each year so that participants in the program can network. NMSU also offers first- and second-year faculty a more intensive team mentoring program. In regular meetings, protégés receive help from their peers, as well as from the director of the faculty development center. Protégés interview three potential mentors before selecting one (Gray \& Birch, 2008).

Many new faculty need mentoring as soon as they are hired and before they are in a position to select an appropriate mentor. At BYU, the center encourages department chairs to assign an experienced faculty member to assist new faculty during their first semester. New faculty are then encouraged to get to know colleagues, build relationships, and choose a longterm mentor by the beginning of the second semester. Before inviting someone to serve as their mentor, new faculty must have their choice approved by their department chair, who may be aware of reasons that a particular mentor would not be the best choice. After mentors are chosen, mentors and their protégés participate in joint training to help them learn how and think about how to establish a successful mentoring relationship. During this training, the mentoring pair discusses their goals for the relationship and determines a specific day and time they can meet regularly. They are encouraged to make this a mutually beneficial relationship by, for example, working on joint projects that serve both partners' interests.

The center at UMass directs a mutual mentoring initiative that promotes an innovative hybrid of traditional mentoring and professional networking. Unlike the traditional one-on-one mentoring relationship between a tenured faculty member and pretenure protégé, mutual mentoring encourages the development of a nonhierarchical network of support in which early-career faculty work with a range of mentoring partners to share their areas of experience and expertise for mutual benefit. The model is carried out through two grant programs. Team grants are for large group mentoring that support faculty-designed projects at the departmental, college, interdisciplinary, or interinstitutional levels. Microgrants are for small group mentoring that encourages earlycareer faculty to identify areas for professional growth and develop the necessary mentoring relationships to make such change possible. Partners focus on a wide array of self-selected topics, including research productivity, teaching development, tenure preparation, and work-life balance. Mentoring networks demonstrate every possible variation of mentoring: peer, near peer, senior to junior, one-on-one, small group, large group, 
face-to-face, and online. (Mentoring exemplars and a guide for mentoring partners and department chairs are available at www.umass.edu/ofd/ mentoring/Mutual\%20Mentoring\%20Guide\%20Final\%2011_20.pdf.)

In addition to formal programs, centers can help faculty widen their network of mentoring partners in other ways. Center workshops and seminars should be designed to help early-career faculty get to know each other and meet experienced faculty and key administrators. Faculty developers help build collegial networks by using name tags, sharing names and e-mail lists with participating faculty, emphasizing learning communities or workshop series versus one-time offerings, and providing informal opportunities to network such as meals and receptions. All of these strategies encourage the development of mentoring relationships and possible teaching and scholarly collaborations.

\section{Scholarly Writing}

Faculty members need support for scholarly writing and publishing. Three interventions that help faculty produce more and better scholarship are workshops on writing productivity, writing groups, and writing coaches. For each of these interventions, when pre- and postdata were available, publication rates improved at least twofold (McGrail, Rickard, \& Jones, 2006). Writers' retreats can also help jump-start writing, provide synergy to writers, and help writers push through barriers they encounter (Elbow \& Sorcinelli, 2006; Murray \& Newton, 2009).

Boice (1997) found that academics, regardless of discipline, teaching load, or type of institution, produce more scholarly writing when they engage in daily writing, keep records of their writing, and hold themselves accountable to someone for doing so. Boice (1989) compared two groups of scholars and found that those who subscribed to these three practices produced more scholarly writing in a year than those who did not by a factor of nine.

Centers may want to include some or all of these practices as part of any intervention to improve scholarly productivity. For example, NMSU and BYU regularly host a writing expert to conduct a four-hour writing workshop on their campuses. The workshop helps faculty and graduate student scholars write daily, keep records, organize their paragraphs around topic sentences, and get meaningful help on their prose from others. After the opening workshop, writing circles of three or four writers meet for one hour weekly for the rest of the semester to support each other in their daily writing and to get feedback on a few pages that they have written each week (Gray, 2010; Gray \& Birch, 2000). 
UMass offers a portfolio of scholarly writing programs for faculty that includes writing retreats, writing spaces, and summer online writing fellowships. Writing retreats have evolved over the years from offering formal writing workshops to offering time and space to help faculty work on their scholarly writing. The center and university library collaborated to create a faculty-only teaching commons in the library that hosts a variety of large-scale and mini-writing retreats throughout the year. These include a long-standing A Room of Your Own retreat in June to help faculty jump-start their summer writing projects; a retreat in August for faculty to prepare for the upcoming semester; a January retreat to make effective use of writing time during winter break; and monthly miniwriting retreats so that faculty can schedule regular, distraction-free writing time. These events feature a quiet, comfortable, fully wired place in which to work. Such writing spaces with few interruptions are important for writing productivity (Boice, 2000), and centers might work with their libraries or other units to establish such spaces. Finally, the center provides summer online writing fellowships facilitated by an experienced local writing coach. Two-month fellowships are offered in June and July. Fellows establish concrete summer writing goals, track their writing progress online, receive online guidance from their coach and fellow peers in the program, and may interact with the writing coach and other participants through an in-person kick-off meeting or a midmonth consultation with the writing coach.

\section{Time Management and Work-Life Balance}

"Finding enough time to do my work" stands out as one of the predominant sources of stress reported in many studies of early-career faculty (Boice, 1992; Rice et al., 2000; Yun \& Sorcinelli, 2009). Difficulties in balancing new responsibilities for teaching, research, and service usually head the list of faculty concerns. Concern about lack of time is a new faculty member's most consistent source of stress across time. One study (Olsen \& Sorcinelli, 1992) found that over their first five years on the job, new faculty became increasingly comfortable with teaching and gained greater clarity and direction in their research agenda. However, their satisfaction with their ability to find enough time to do quality work and to balance the conflicting demands of research, teaching, and service steadily declined. Midcareer and senior faculty also report that work-related stress is frequently related to time constraints-feeling overloaded with work and having little or no time for personal matters (Chu, 2006). 
Centers that address time management can help faculty cope with stress and also boost faculty morale and productivity. Effective time management solutions can be found in the interventions described in earlier sections, for example, providing just-in-time information at orientation, expediting the development of a network of mentors, and encouraging faculty to carve out time to write daily. In addition, centers can host an academic time management consultant. NMSU, BYU, and UMass have all hosted such individuals for campuswide professional development seminars. Such consultants can offer practical strategies to help participants integrate work and personal life and to consciously organize and manage paper, e-mail, and electronic files. Centers may also want to consider linking their website to campus policies and resources for work-life balance. At UMass, these links include help in areas as varied as child care, parental leave, postponement of the tenure decision year for new parents, accommodations for dual-career couples, and elder care.

Even more critical than specific programs, developers may want to consider how their centers' activities can emphasize the importance of managing professional roles and personal lives. One recommendation is to thread this issue throughout other activities provided to faculty by addressing it explicitly or implicitly. Faculty developers may want to ask presenters to keep this issue in mind as part of the context of their remarks for almost any faculty development topic. For example, some faculty choose collaborative work in scholarship as an explicit means to enable them to accomplish each scholar's career goals while also enhancing their personal lives. It is important to recognize and acknowledge that faculty members cannot do it all. They must prioritize, make choices about how to organize their work and their lives, and occasionally say no. Our job as faculty developers is to reassure them that this is true of all faculty members and to help provide support, including guidelines and resources, role models, and constant sensitivity to the complexity of their lives.

\section{Navigating the Tenure Process}

Three problems most commonly identified by early faculty regarding the process of tenure are expectations for performance, feedback on progress, and the collegial review structure (Rice et al., 2000). First and foremost, pretenure faculty members are troubled by unclear, shifting, and conflicting expectations for performance. The lack of clarity around expectations can be exacerbated by insufficient, unfocused, or unclear feedback on performance. Pretenure faculty also believe the problem with feedback 
and evaluation is intensified by several flawed aspects of the tenure and review process itself, which include frequently rotating department chairs, turnover in the membership of personnel committees, and closed committee meetings (Rice \& Sorcinelli, 2002; Tierney \& Bensimon, 1996). Clearly, support in navigating the tenure process is needed. One expert (Lieberman, 2002) calls such assistance indispensable. Nonetheless, sponsoring workshops on the topic of promotion and tenure may move centers closer to the firewall between faculty improvement and faculty evaluation than any other activity. The decision to offer tenure-related programming should be carefully considered and the programs thoughtfully planned with the help of college and university administrators. This initiative might be best launched by longer-standing centers that have considerable respect and support from faculty and administrators.

UMass organizes tenure preparation seminars that directly address pretenure faculty members' concerns about expectations, feedback, and the review process. The center traditionally sponsored a campuswide tenure preparation seminar, but faculty expressed interest in having more local information. As a result, the center now works directly with colleges to cosponsor and custom-design tenure preparation workshops in which college administrators, department chairs, and faculty help to design and exclusively lead the seminars. In this way, the center is seen as enabling the sharing of best practices rather than having any involvement in personnel processes. Workshops typically include a welcome from the dean, a step-by-step overview of the tenure process by an associate dean, and a panel discussion with a department chair and past members of the department and school and college personnel committees. The formal program concludes with a panel discussion with three or four recently tenured faculty members who share general strategies for achieving tenure. A reception follows the event so that pretenure faculty members can talk with their chairs, deans, and personnel committee members in a relaxed setting.

The NMSU center hosts two university-wide half-day pretenure workshops a year. During the fall and spring workshops, participants listen to the provost and several other speakers and panels. Participants are seated by college and bring their promotion and tenure packets along with questions to ask their deans and promotion and tenure committee members, who also attend. In the summer, the center offers a week-long tenure portfolio workshop. Participants meet for two hours a day for feedback on successive drafts from a mentor chosen by their college dean. (Often this mentor is the head of the college promotion and tenure committee.) The center also keeps a set of current promotion and tenure packets in its 
library for reference, and the skeleton of these packets is available online. The center director and one associate director are available on request to help faculty prepare their packets.

As an alternative, developers can shape existing programs to help new faculty make progress toward tenure. For example, at BYU, promotion and tenure is a topic that comes up frequently during the eighteen-month new faculty program. During this program, the center helps faculty frame their priorities so that they are striving for excellence in their professional responsibilities rather than just jumping through hoops to get tenure. Assuming the goals are worthy and faculty succeed in accomplishing them, promotion and tenure should largely take care of themselves. Nevertheless, it is important to make sure the university's expectations are clear. New faculty and chairs are encouraged to meet regularly to discuss expectations. During the first semester and again during the two-week seminar in May, the associate academic vice president talks to new faculty about managing the evaluation process. The center also collaborates with college-level administrators to provide college-specific meetings on promotion and tenure during the May seminar. Finally, the center maintains an ongoing discussion with university administrators, providing research and advice to help improve the promotion and tenure process for all faculty members, including reviewers.

\section{Leadership and Service}

Just as graduate school does not prepare one to be an assistant professor, achieving tenure does not prepare one to be a midcareer faculty member. Service and administrative duties begin to take up considerable faculty time right after tenure (Baldwin, Lunceford, \& Vanderlinden, 2005). Faculty who are asked to assume a range of administrative roles after tenure often have little leadership experience or training. The steep learning curve and time required to feel confident as an academic leader can have a negative impact on the overall quality of a university's day-to-day functioning.

New chairs, heads, and directors of programs take on roles with an influence that in many ways can rival that of a chancellor (Chu, 2006). Because the department is the locus for a great deal of the university's work, these administrators are called on to make serious personnel, budget, and curricular decisions. Faculty developers recognize the importance of supporting departmental leadership and have offered aspiring, new, and seasoned leaders the opportunity to share ideas, discuss problem situations, and brainstorm solutions in a safe environment (Sorcinelli et al., 2006). 
When teaching centers provide this help, Lucas (2002) notes that they increase their impact.

UMass has developed two year-long programs: one to support new department chairs, heads, and directors and one to expose assistant professors to administrative careers in an effort to develop our own academic leaders. The chair leadership program offers monthly luncheon seminars led by seasoned chairs and administrators and focuses on topics selected by participants, such as budgeting during difficult times, time management, and managing conflict, as well as a campus update and feedback session with the provost and dean of the faculties. On behalf of the chancellor's office, the center also coordinates the Chancellor's Junior Faculty Fellows Program, which fosters an exchange of ideas between the campus's central administration and promising new faculty members who might be interested in campus leadership in the future. As part of the program, fellows meet regularly each semester with the chancellor to discuss the university's direction and how the central administration can assist pretenure faculty as they accomplish their professional goals.

Alternately, centers may want to focus leadership efforts on tenured faculty leaders as well as sitting department chairs. NMSU's center directs a year-long leadership program designed to help campus leaders (including department chairs) become familiar with university issues and get hands-on experience in identifying and solving university-wide problems. The program begins with a two-day retreat based on the principles of Stephen Covey's 7 Habits of Highly Effective People (1989). The retreat is followed by a series of three-hour monthly meetings in which participants hear from various administrators for an hour and work for the next two hours on a Provost's Project. This is a research project that the participants undertake collectively to help the provost with a campuswide problem. The topic is selected by the participants in consultation with the provost. Previous topics include campuswide communication, reallocation of faculty lines, academic integrity, and why NMSU faculty leave and why they stay. At the end of the year-long project, the Provost's Project is presented to the provost with recommendations for institutional improvement in areas such as communication and shared governance, resulting in policy and procedural changes on campus. In addition, the new provost at NMSU has asked the center to establish a department head academy, which will provide one or two programs monthly and a two-day retreat in May for both deans and department heads.

A multilayered set of programs supports department chairs at BYU, where a department chair coordinating council directs department chair training. 
A website, which is accessible to other campus administrators, provides information on all chair tasks with attendant policies, forms, calendars, directories, and other resources. Events are organized around policy, dialogue, and leadership. Policy events consist of regular seminars for new chairs, directed by the associate academic vice president for faculty. Topics cover core aspects of chairing associated with policy: hiring, annual reviews, promotion and tenure, finances, and budgets. Dialogue events facilitate informal interactions among chairs through brown bag discussions held monthly to address topics selected by chairs and one-on-one lunches (paid by the center) to which a new chair can invite a veteran chair. Example dialogue topics include setting academic standards, departmental governance, and giving and receiving feedback. Leadership events consist of occasional workshops to which all academic administrators are invited; these often feature someone of prominence from off campus. Example leadership topics include building functional teams and handling difficult conversations.

\section{First Steps and Concluding Thoughts}

When faculty development programming goes beyond instructional development, faculty benefit by having opportunities to develop in their multiple roles; faculty developers benefit because participation at these events tends to be higher and spills over into instructional development events; and institutions benefit through improved faculty performance and satisfaction. As developers consider whether to respond to emerging areas of practice, they might wonder if their center is large enough or well-enough established to tackle these issues, how to prioritize expansion efforts, or whether they will just invite "mission creep." Center personnel might begin by reflecting on the following questions: What are the noticeable gaps in supporting faculty work on campus that your center might fill? Does the initiative fit within your mission and values? Will it represent your center well? What are the needed resources-staff time and budget? Is this a good use of those resources? How broad an audience will this initiative reach? Can your center work in partnership with other units (say, research affairs or the library) or academic leaders (such as department chairs, deans, or the provost) to further mutual agendas for enhancing faculty careers?

In getting started, very new and small centers might begin by addressing new faculty orientation, scholarly writing, or time management, issues that are central to faculty life and for which programming is relatively easy to put together. Larger, more mature centers are more likely to have the 
resources and experienced faculty development professionals to address mentoring, career advancement, leadership, and service. Ideally, responding to a broader mission will not only allow a center to better address the needs of the whole faculty member and the broader institution, but also expand the expertise, reach, and potential of the center itself.

\section{REFERENCES}

Baldwin, R. G., Lunceford, C. J., \& Vanderlinden, K. E. (2005). Faculty in the middle years: Illuminating an overlooked phase of academic life. Review of Higher Education, 29(1), 97-118. doi:10.1353/rhe.2005.0055

Bensimon, E. M., Ward, K., \& Sanders, K. (2000). The department chair's role in developing new faculty into teachers and scholars. San Francisco, CA: Jossey-Bass.

Boice, R. (1989). Procrastination, busyness and bingeing. Behavior Research Therapy, 27(6), 605-611. doi:10.1016/0005-7967(89)90144-7

Boice, R. (1990). Mentoring new faculty: A program for implementation. Journal of Staff, Program, and Organizational Development, 8(3), 143-160.

Boice, R. (1992). The new faculty member: Supporting and fostering professional development. San Francisco, CA: Jossey-Bass.

Boice, R. (1997). Strategies for enhancing scholarly productivity. In J. M. Moxley \& T. Taylor (Eds.), Writing and publishing for academic authors (pp. 19-34). Lanham, MD: Rowman \& Littlefield.

Boice, R. (2000). Advice for new faculty members: Nibil nimus. Needham Heights, MA: Allyn \& Bacon.

Chu, D. (2006). The department chair primer: Leading and managing academic departments. San Francisco, CA: Jossey-Bass.

Covey, S. R. (1989). The seven habits of highly effective people: Powerful lessons in personal change. New York, NY: Simon \& Schuster.

Elbow, P., \& Sorcinelli, M. D. (2006, November/December). The faculty writing place: A room of our own. Change, 38(6), 17-22.

Goodwin, L. D., \& Stevens, E. A. (1998). An exploratory study of the role of mentoring in the retention of faculty. Journal of Staff, Program, and Organizational Development, 16(1), 39-47.

Gray, T. (2010). Publish and flourish: Become a prolific scholar. Las Cruces: New Mexico State University, Teaching Academy.

Gray, T., \& Birch, A. J. (2000). Publish, don't perish: A program to help scholars flourish. In D. Lieberman \& C. Wehlburg (Eds.), To improve the academy: Vol. 19. Resources for faculty, instructional, and organizational development (pp. 268-284). San Francisco, CA: Jossey-Bass. 
Gray, T., \& Birch, A. J. (2008). Team mentoring: A participatory way to mentor new faculty. In D. R. Robertson \& L. B. Nilson (Eds.), To improve the academy: Vol. 26. Resources for faculty, instructional, and organizational development (pp. 230-241). San Francisco, CA: Jossey-Bass.

Gray, T., \& Shadle, S. E. (2009). Launching or revitalizing a teaching center: Portraits of practice. Journal of Faculty Development, 23(2), 5-12.

Johnson, W. B. (2007). On being a mentor: A guide for higher education faculty. Mahwah, NJ: Erlbaum.

Johnsrud, L. K., \& Atwater, C. D. (1993). Scaffolding the ivory tower: Building supports for faculty new to the academy. CUPA Journal, 44(1), 1-14.

Lee, V. (2010). Program types and prototypes. In K. J. Gillespie, D. L. Robertson, \& Associates, A guide to faculty development (2nd ed., pp. 21-34). San Francisco, CA: Jossey-Bass.

Lieberman, D. (2002). Nurturing institutional change. In C. M. Schroeder \& Associates, Coming in from the margins: Faculty development's emerging organizational development role in institutional change (pp. 60-73). Sterling, VA: Stylus.

Lucas, A. (2002). Increase your effectiveness in the organization: Work with department chairs. In K. J. Gillespie (Ed.), A guide to faculty development: Practical advice, examples, and resources (pp. 2-8). San Francisco, CA: Jossey-Bass.

McGrail, M. R., Rickard, C. M., \& Jones, R. (2006). Publish or perish: A systematic review of interventions to increase academic publication rates. Higher Education Research and Development, 25(1), 19-35. doi:10.1080/07294360500453053

Morahan, P. S., Gold, J. S., \& Bickel, J. (2002). Status of faculty affairs and faculty development offices in U.S. medical schools. Academic Medicine, 77(5), 398-401.

Murray, R., \& Newton, M. (2009). Writing retreat as structured intervention: Margin or mainstream? Higher Education Research and Development, 28(5), 541-553. doi:10.1080/07294360903154126

Olsen, D., \& Sorcinelli, M. D. (1992). The pretenure years: A longitudinal perspective. In M. D. Sorcinelli \& A. E. Austin (Eds.), New directions for teaching and learning: No. 50. Developing new and junior faculty (pp. 15-25). San Francisco, CA: Jossey-Bass.

Palmer, M. M., Dankoski, M. E., Brukiewicz, R. R., Logio, L. S., \& Bogdewic, S. P. (2010). Rx for academic medicine. In L. B. Nilson \& J. E. Miller (Eds.), To improve the academy: Vol. 28. Resources for faculty, instructional, and organizational development (pp. 292-309). San Francisco, CA: Jossey-Bass. 
Rice, R. E., \& Sorcinelli, M. D. (2002). Can the tenure process be improved? In R. P. Chait (Ed.), The questions of tenure (pp. 101-124). Cambridge, MA: Harvard University Press.

Rice, R. E., Sorcinelli, M. D., \& Austin, A. E. (2000). Heeding new voices: Academic careers for a new generation. Sterling, VA: Stylus.

Schuster, J. H., \& Finkelstein, M. J. (2006). The American faculty: The restructuring of academic work and careers. Baltimore, MD: Johns Hopkins University Press.

Sorcinelli, M. D., Austin, A. E., Eddy, P. L., \& Beach, A. L. (2006). Creating the future of faculty development: Learning from the past, understanding the present. San Francisco, CA: Jossey-Bass.

Sorcinelli, M. D., \& Yun, J. (2007, November/December). From mentor to mentoring network: Mentoring in the new academy. Change, 39(6), 58-61.

Tierney, W. G., \& Bensimon, E. M. (1996). Promotion and tenure: Community and socialization in academe. Albany: State University of New York Press. van Emmerik, I.J.H. (2004). The more you can get the better: Mentoring constellations and intrinsic career success. Career Development International, 9(6), 578-594. doi:10.1108/13620430410559160

Yun, J. H., \& Sorcinelli, M. D. (2009). When mentoring is the medium: Lessons learned from a faculty development initiative. In L. B. Nilson \& J. E. Miller (Eds.), To improve the academy: Vol. 27. Resources for faculty, instructional, and organizational development (pp. 365-384). San Francisco, CA: Jossey-Bass. 